\title{
Physiology of Saliva: An Overview
}

\author{
Abhay K. Pandey \\ Department of Physiology, All India Institute Of Medical Sciences, Bhopal, Madhya Pradesh, India \\ Correspondence e-mail to: abhay.physiology@gmail.com
}

\begin{abstract}
Physiology of saliva evolves in supporting many important activities in human life. Changes in age, environmental and living condition as well as eating habit would influence salivary function. Saliva palys a role in determining the development pattern and oral health. Saliva has a unique function in the defense mechanism to microorganism in the oral environment. Research focuses on the salivary physiology is limited and seems to be separated from medical and dental professional education. Better and deeper comprehensive understanding of saliva in health and disease is needed. Nowadays, many studies have used saliva to find diagnosis markers for specific diseases. Salivary analysis is intended to give descriptive information on disease status for prevention, monitoring and treatment purposes. This brief review aimed to give understanding on salivary physiology in order to add new views of its application in the field of medicine and dentistry.
\end{abstract}

\begin{abstract}
ABSTRAK
Fisiologi saliva: sebuah ringkasan. Kondisi fisiologi saliva mempunyai peran penting dalam kehidupan manusia. Perubahan yang terjadi pada usia, kondisi lingkungan, kehidupan dan pola makan mempengaruhi ada atau tidaknya gangguan fungsi saliva. Saliva berperan dalam menentukan pola pertumbuhan dan kesehatan gigi di dalam rongga mulut. Saliva merupakan cairan unik yang berfungsi dalam mekanisme pertahanan utama mikroorganisme yang ada di dalam rongga mulut. Penelitian tentang fisiologi saliva, selama ini sepertinya dipisahkan pendidikan profesi kedokteran dan kedokteran gigi. Oleh karena itu, diperlukan pengertian yang lebih baik dari tentang saliva secara menyeluruh dalam kondisi sehat dan sakit. Saat ini telah banyak penelitian yang dilakukan untuk menggunakan saliva untuk mencari penanda diagnosis suatu penyakit. Analisis saliva juga diharapkan dapat memberikan gambaran tentang status kepenyakitan dan membantu untuk pencegahan, monitoring dan perawatan. Telaah singkat ini dibuat untuk memberikan pengertian tentang fisiologi saliva untuk menambah wawasan baru tentang fisiologi saliva dan aplikasinya dalam bidang kedokteran dan kedokteran gigi.
\end{abstract}

Key words: caries prevention, oral biology, oral hygiene, saliva, salivary function,

\section{INTRODUCTION}

Physiology emphasizes normal constitution (static) and regulation (dynamic) of functional systems. The understanding is essential to conceive aberrations, their origins and consequences, and rational ways to rectify or prevent them to maintain healthy state. The significance of saliva physiology to both oral and systemic health is enormous. Saliva represents the research sphere of first Nobel Prize in medicine and physiology, awarded in 1904 to Ivan Petrovich Pavlov. It constitutes the unique and dynamic ecologic milieu of oral cavity. Multiple components in saliva participate in homeostasis vital to health of oral structures. Lubrication of oral tissue facilitates speaking, chewing and swallowing. Hydrodynamic flushing serves debridement and levage. Saliva has key role in safeguarding hard and soft oral structures to ensure smooth feeding and nutrition. Strength of teeth and resistance to pathogen invasion are most prominent in this regard. 
Saliva derives components from several sources. Proteolytic activity within saliva also generates new molecules. These, both independently and synergistically, execute to salivary function with clinical impacts. 'Redundancy of constituents' is uniquely manifest in saliva at multiple levels. There is multiplicity of salivary glands, the major ones being in pairs. There are specific and shared constituents in different glandular secretions including polymorphism in salivary protein families. Nevertheless they serve identical functions. Salivary complexities of constitution and function have evolved over changing food habits of mankind in diverse environments. Biomedical secrets of saliva are far from being adequately revealed yet significant to health and disease. Their significance increases with increase in aged population and chronic diseases. Periodical review of understanding of physiology of saliva increased by advances in study techniques is thus important.

\section{Constitution and dynamic changes in saliva}

Continuous salivary secretion coating oral structures mostly derives from mucus rich submandibular gland fluid. Parotid secretion dramatically overtakes this upon stimulation, providing bicarbonate to buffer ingested acidic products and amylase to cleanse starchy food sticking oral structures by digestion. Type and strength of evoking stimulus determines saliva flow rate and thus relative composition. Transepithelial chloride movement drives fluid and electrolyte output consequent to stimulation. Five channel types with different gating mechanisms are defined. System employing calcium influx as second messenger drives fluid release while cyclic-AMP (cAMP) linked system promotes sodium and chloride reabsorption in salivary ductal epithelium. Cell volume sensing and agonist gated channels also modulate the fluid and electrolyte movement. ${ }^{1,2}$ Saliva reaches oral cavity as hypotonic fluid relative to plasma. Autonomic parasympathetic stimulation releases fluid while sympathetic stimulation causes outpouring of stored components of glandular cells, although decreasing volume due to vasoconstriction and diversion of blood supply. ${ }^{3,4}$ Systemic hydration has major bearing on volume of salivary secretion and loss of around tenth of body water would virtually shut down salivary output. Exercise and excretion over prolonged period that elevate sympathetic activity, also compromise salivary protection of oral structures. ${ }^{5}$ Basal unstimulated saliva production declines with aging and associated chronic diseases as diabetes, and stimulated parotid and submandibular outputs are also lower. ${ }^{6-8}$ States of anxiety, stress or depression implying neurohumoral mechanisms and female sex (estrogenic influence) associate with varying compromise in quantity and composition of salivary secretion..$^{9,10}$
Normal flow rate or salivary output is vital defence against caries. Inflammation of oral structures is responded to by mounting protective profile of saliva which reverts to normal when the state subsides. ${ }^{11}$ Neuro-regulation consequent to specific stimuli effects high output of phosphate, amylase and other bioactive proteins in salivary secretion..$^{2,12-14}$ Adequate presence of these even in unstimulated secretion is critical to oral protection. ${ }^{15}$ Extensive modification of salivary proteins occurs in oral environment with microbial enzymes. Physiological role of saliva is subject to balance of fresh secretion and removal by swallowing. That determines turnover of independent or synergistic combination of the constituents. ${ }^{16}$ Local and systemic disorders diversely inflict functional deficits in saliva. Their understanding is important in salivary diagnosis, preventive or corrective interventions and monitoring of relation to disease activity. Salivary dysfunction causes difficulty in bolus making and mastication, swallowing, proper taste perception etc. ${ }^{17}$ Increasing aging population, obesity and metabolic syndrome and stress of modern life are blowing up magnitude of salivary dysfunction. These call for improved understanding and address.

Researches on cystic fibrosis in past may be recalled for renewed application to perspectives. ${ }^{18}$ Disorder specific interventions may suggest from elucidation of stepwise progression of signal transduction in stimulus-secretion coupling. Salivary system beholds variety of biochemical molecules and their receptors e.g. substance $\mathrm{P}$, neuropeptide $\mathrm{K}$, vaso-active intestinal peptide, CCK and other gut hormones, nitric oxide and carbon monoxide. ${ }^{19,20}$ Their action and interaction within saliva in health and disease deserve elucidation. Personal habits as smoking and drinking as well as states of under/ malnutrition cause structural and functional changes in salivary glands. ${ }^{21,22}$ Susceptibility to infection would increase due to compromise of nitric oxide formation in smokers where activated arginase depletes the precursor. ${ }^{23,24}$ While nutritive value of diet is important, selection of food items also matters. Whole grain foods require greater mastication that stimulates cholinergic boost to salivary flow improving functional profile..$^{14}$ Drugs affecting autonomic nervous function would have predictable effects while others, as antiepileptic's beer novel adverse mechanisms of compromising salivary defence mechanism. ${ }^{25,26}$ Phenolic tannins from plant foods have multifaceted interaction and effect on saliva function. They precipitate mucin but simultaneously add to inactivation of cariogenic microbial enzymes. The resultant reduction of viscosity improves flushing and cleansing of sticky food matter by saliva. ${ }^{27}$ 


\section{Regulation of salivary $\mathrm{pH}$}

Maintenance of oral $\mathrm{pH}$ above 5.5 is necessary to avoid dissolution of calcium salt from enamel leading to tooth erosion. Normal salivary $\mathrm{pH}$ varies in the range from 5.75 to 7 , which may rise further up to 8 upon stimulated secretion. Salivary proteins, phosphate and bicarbonates contribute to $\mathrm{pH}$. Proteins being largely ionized have minor bearing and phosphate is major determinant of $\mathrm{pH}$ at resting state in saliva. Saliva remains super saturated with calcium phosphate whose concentration relates inversely to the $\mathrm{pH}$. Bicarbonate input overtakes $\mathrm{pH}$ maintenance upon stimulated salivary secretion. ${ }^{28,29}$ This helps combat acid insult of drinks, juices, gastro-esophageal efflux, and food fermentation by microbes in dental plaque, drugs, fumes etc. Acid formed under plaque is readily converted to bicarbonate in salivary fluid which readily breaks down and exhaled as carbon dioxide. $\mathrm{pH}$ is thus checked from falling below 5.5. Saliva also becomes more viscous with fall of $\mathrm{pH}$.

\section{Dental pellicle}

At ordinary $\mathrm{pH}$, phosphate groups of hydroxyapatite on enamel surface bear negative charge that attracts positively charged calcium ions from saliva. The hydrated covering layer of enamel thus, gains strong positive charge. This can sequentially attract negatively charged sulphate and phosphate groups of salivary acidic glycoproteins. Progressively variety of salivary macro-molecules get adsorbed and incorporated in the covering sheath. The later include lysozyme, alpha amylase, peroxidases, immuno-globulin A and G, proline rich glycoproteins (PRG).

The enamel covering sheath bearing active biomolecules is termed as pellicle. ${ }^{30-32}$ There is covalent cross linking among pellicle proteins protective against abrasion and attrition of enamel and serves as barrier to diffusion. ${ }^{33}$ Pellicle liquid is relatively undisturbed and molecular movements without diffusion force are minimum in contrast to salivary coating elsewhere. Pellicle itself is insoluble, retarding transport of matter across enamel. Enamel solubility is thus held in check. ${ }^{34}$ Free floating salivary microbes attach the pellicle forming aggregates or clumps, readily removed as saliva is swallowed. Aerobic bacteria retain the attachment better and initially multiply upon pellicle to form plaque, the yellowish fast adhering deposit on teeth. Pellicle bears receptor sites for specific microbial adhesins. Further thickening of plaque allows predominance of anaerobes in deeper layers. Bacteria derive nutrition from breakdown of acellular matrix of pellicle, with some utilizing eluted metabolites of other species and thus displaying a symbiont community. Increase in proteolytic process, urea formation and rise in $\mathrm{pH}$ promote mineral deposit in plaque, forming crust and calculus. ${ }^{35}$ Regular removal of bacterial plaque is necessary to prevent spread of bacterial toxins to gums, causing periodontal disease.
Decrease in salivary flow rate increases such risk. Research continues on molecular strategies that would effectively prevent pathogen adhesion. ${ }^{36,37}$ Studies of changes in pellicle constituents and their effect on permeability profile, i.e. lipid removal; and elaboration of specifics of microbe-pellicle interaction, form prominent research perspective. ${ }^{38}$

\section{Dentine mineralization}

Pellicle provides essential barrier to acid insult for newly erupted teeth, which mature under its anchorage by substitution of hydroxy-apatite mineral. ${ }^{39}$ Richly glycated mucoproteins in pellicle are resistant to acid peptic degradation and bear visco-elastic strength. Their negative charge intercepts continuous deposition of calcium phosphate and avoids blockage of exchange pores of enamel surface, allowing speedy mineralization process. ${ }^{40,41}$ The pellicle is kept supersaturated in calcium and phosphate by constituent proline rich glycoproteins and statherin. ${ }^{42,43}$ It thus serves as resource to reminerallization. Fluoride from saliva selectively accumulates in pellicle and forms complex with enamel hydroxy-apatite. Fluoride plays part in reminerallization at higher $\mathrm{pH}$, avoidance of excess calcium phosphate precipitation and resistance to acid erosion. ${ }^{41,44,45}$ Salivary proteins with varying functions generally bear parallel role in maintaining integrity of hard and soft oral tissues. Cystatins participating in pellicle formation help maintaining hydroxyl-appetite crystal equilibrium and inhibit proteolysis. ${ }^{46}$ Proteins from submandibular gland secretion counter inflammatory damage of tissues. PRGs support enamel reminerallization through keeping saliva supersaturated in calcium phosphate and preventing undue precipitation of salt. ${ }^{47}$ The calcium ions stimulate intermolecular interactions of salivary proteins to form the unique network structure with select globular aggregates called micelles..$^{36,48-50}$ Enamel is not in contact of blood, hence entirely dependent on saliva for it reminerallization.

Stable acids from food and those produced by bacterial activity are threats for mineral dissolution. Carbonic acid formed of carbon-dioxide in breath in salivary water is key mediator in mineralization. Initially it would dissolve food and enamel mineral but also break down and readily release the same. In fact the mineral is made available to wanting sites of the enamel for mineralization. Saliva must be mineral rich and teeth must be clean to best enable uptake of mineral at deminerallized sites. Wild animals feeding on mineral rich coarse diet requiring much mastication and salivation do not suffer caries as frequently. Altered ionic composition of saliva also carries risk of caries. People hearing extensive caries show low molar ratio of zinc and copper. ${ }^{2,12}$ These elements are constituents of antioxidant enzymes. ${ }^{38}$ Intriguing is the fact that zinc is also constituent of matrix metalloproteinase which are salivary and tissue agency for matrix dissolution 
and remodeling. ${ }^{14}$ There is inverse relation of caries risk to copper and iron contents in saliva. ${ }^{18}$ Altered composition of trace elements in saliva following exertion may be contributory to increased caries risk, besides overall decrease in salivary flow rate. ${ }^{51}$

\section{Anti-microbial defence}

Sticky mucoproteins of saliva provide barrier to dessication, penetration, ulceration and exposure of oral epithelium to toxins and carcinogens. Degree of glycation of the mucoproteins is key to protective capabilities. $^{25,52}$ Total protein bound sugar in normal saliva is in range of $300-400 \mu \mathrm{g} / \mathrm{ml}$. The glycosaminoglycans confer visco-elasticity, hindrance to precipitation, proteolysis and serve antigenic function. These also carry blood group antigens that may hinder binding of some pathogens as well. ${ }^{53} \mathrm{It}$ is however the very salivary proteins PRGs, alpha amylase and statherin in the pellicle that bear receptors to bind gram negative bacteria making commensales in oral cavity. Gram positive organisms and candida may super add to the community. Low molecular weight mucin and lysozyme clump the bacteria increasing clearance and reducing colonization of the plaque., Innate defence system of saliva includes lysozyme, lactoferin, peroxidase, histatin, basic side chain polypeptides and mucin. Some of these are bacteriolytic or bacteriostatic while others promote their clearance. ${ }^{8}$

Lysozymes are strongly cationic and disrupt bacterial cell wall resulting in autolysis. Gram negative bacteria resists such actions by lipo-polysaccharide in their cell wall. Peroxidases impair glucose utilization in microbes by catalyzing oxidation of sulphhydryl groups and inactivating microbial enzymes which degrade proteins in saliva. ${ }^{16,54}$ Histatin has broad antimicrobial spectrum including anti-candidial activity. Strong positive charge of histatin disrupts microbial cell membrane. Inhibition of oral mast cell mediator release by histatin is suggestive of anti-inflammatory function. Separate structural determinants of histatin molecules carry out antibacterial, anticandidial effects and promotion of healing of mucosal wounds. ${ }^{55}$ Salivary lactoferin mostly comes from admixture with gingival crevicular fluid and sex hormones in female increase lactoferin content of saliva. ${ }^{56}$ Lactoferin interferes with receptors on glycosaminoglycans in pellicle and oral surface and resists pathogen adhesins and formation of biofilm. ${ }^{57}$ Biofilm formation is critical determinant of resistance of the bacteria to chemotherapeutic agents. Lactoferin deprives the iron availability by strong chelating action essential to bacterial survival and growth. This simultaneously reduces iron catalyzed free radical generating events characterizing persisting inflammatory states such as periodontitis. Lactoferin also inactivates lipo-polysaccheride toxins of pathogenic gram negative microbes and down regulates production of proinflammatory cytokines in chronic periodontitis. ${ }^{58}$
Salivary immunoglobulin IgA is main adaptive immune mechanism in oral cavity. Besides the possibilities of prior exposure and priming to an antigen, the salivary IgA response is also under strong neuro-endocrine regulation. ${ }^{59}$ Exercise, stress, menstrual cycle, pregnancy and drugs thus, affect IgA secretion in saliva.$^{60,61}$ Origins transport and property of $\operatorname{IgA}$ in health and disease patterns the local and the common mucosal immunity. ${ }^{62}$ IgA neutralizes viruses, bacteria toxins and enzymes. Immunoglobulin $G$ is minor component derived from gingival crevicular fluid. Immunoglobulin's agglutinate bacteria and prevent mucosal affliction.

\section{Protection against inflammatory damage and repair}

Under stress conditions IgA secretion is accompanied with increased cortisol and its conversion to cortisone in salivary glands. The mechanism appears to check inflammatory over reaction. Calcitonin gene related peptide adrenomedulin is also secreted in saliva with direct bacteriolytic property and promotes recruitment of leucocytes to site of insult. ${ }^{39}$ Melatonin in saliva is important in controlling inflammation associated oxidative stress and promotion of healing. ${ }^{1,2}$ Apart from histatin, saliva also contains epidermal growth factor and vascular endothelial growth factor helping regeneration of oral tissue. Genes of a variety of cytokines express in salivary glands, specially the sub-mandibular glands. ${ }^{63}$ Their increased transcription in specific diseases apparently serves modulation of inflammatory response in oral structures. ${ }^{28,64}$ Increased epidermal growth factor and leptin particularly occurs upon needs for repair and regeneration. Leptin also counters lipo-polysaccheride induced inhibition of salivary mucin secretion. ${ }^{29}$ Epidermal growth factor causes speedy angiogenesis and cell proliferation. Coagulation factors in saliva may be helpful in boosting haemostasis. Salivary kallikerin induces dilation of microvasculature around mucosal wounds, reinforcing the nutrient and oxygen supply at site. ${ }^{65}$

\section{Taste, nutrient sensing and regulation of intake}

Taste perception is influenced by state of salivary function and hormones in saliva that have receptors on taste receptor cells (TRCs). Salivary physiology is thus linked to general metabolism via activation of cognate taste receptors. Once food is taken in oral cavity, taste receptors relay signal to brain stem and higher centers through gustatory nerves. Glucose sensitive insulin production in salivary glands is proposed. ${ }^{66}$ Insulin sensitizes salt taste reducing salt intake. ${ }^{7}$ In contrast, salivary glucagon boosts sweet taste increasing food intake. ${ }^{21}$ Fasting salivary levels of glucose dependent insulin like peptide (GLP) and gut hormone incretins are many folds higher in saliva than in plasma. ${ }^{67}$ These affect gut motility and following food intake, promote 
gastric acid secretion. CCK receptors cluster on bitter taste receptor cells with apparent modulatory role. Salivary ghrelin modulates salt and sour taste signals. ${ }^{68}$ Salivary leptin displays circadian variation and inhibits sweet consumption by negative modulation of sweet taste. It also serves as growth factor for oral mucosa. ${ }^{69}$ Several peptide hormones in saliva also suppress sweet taste. Multiple paracrine mechanisms regulate taste function, appetite and descriminant food intake. This appears to be distinct physiological mechanism of digestive system which employs detection of food for pre absorption control mechanisms as well as mounting appropriate sensory motor response to meals. Signals to brain as well as adipocytes appear involved..$^{17,70}$ Altered ionic composition of saliva due to admixture of serum, results in altered taste perception, linking to altered central dopaminergic mechanism in pathogenesis of burning mouth syndrome, a local neuropathic disorder. ${ }^{71}$ Elderly generally have much albumin mixed in saliva.

\section{Diagnostic tool}

Salivary diagnostics is very attractive due to scope of non invasive collection, constant availability, feasible to study without complex instrumentation, and very cost effective process. ${ }^{44,45}$ This most suits mass screening for disease detection. Salivary proteins like any other would carry genetic imprint of differences and disorders. There is promising perspective of phenotyping and understanding pathogenesis of genetic diseases. Many plasma compartment proteins freely appear in saliva. Comparative protein profiling of saliva and plasma would reveal the overlapping moieties that may be candidates to serve as valid systemic biomarkers in health and disease. Changes in salivary proteins can help in principle, diagnosis and monitoring of disease activity including response to therapeutic interventions. Current identification of salivary proteins is however pretty incomplete. Catalouging of salivary protein constituents is crucial to optimal diagnostic use of saliva and is subject to advance with modern omics technologies. Origin, composition, function and interaction aspects of salivary constituents are prerequisites for understanding to prudent diagnostic contemplation. Exchange between plasma and saliva forms basis for systemic diagnosis. Mixing of saliva with secretory, exudative and waste products from oropharynx, airway, gingiva and esophagus has significant bearing for regional and local diagnostics, especially of neoplasia. ${ }^{72}$

\section{Future perspectives}

Increasing longevity and prevalence of chronic diseases calls for greater attention to salivary function, dysfunction and therapeutic address. Saliva flow rate is crucial determinant of salivary function by virtue of controlling all the players. Optimal flow rate varies among the individual subjects. Relevant functional parameters are obviously assayed as bacteria aggregation profile, interference potential for bacterial adherence to hydroxyapatite, relative content of sugar in salivary muco-proteins etc. The in vitro investigations help characterizing potential caries protective mechanisms without any means to weigh their in vivo implications. Variations in composition and function of saliva also accompany phases of life and state of living amid varying strains and stresses and systemic chronic disorders. Intrinsic host factors, preventing pathogens from overwhelming salivary defence nevertheless, are crucial components active alone and in peculiar synergy. Definition of susceptibility perspectives would open up new possibilities for preventive and therapeutic interventions. Efforts to develop feasible booster of IgA response as caries vaccine, exemplifies this. ${ }^{73,74}$ Change of host oral environment must affect microbial gene expression and composition of resident micro flora. Changes that disrupt symbiotic community, increasing vulnerability to disease, deserve ample elaboration. Cellular kinetics of proteins shared between saliva and plasma may bear similarity and yet physiologic role may differ in the specific domains. Comprehensive study of stimuli and stressors that particularly increase presence and quantity of a protein in saliva may hint functional connections to defence or homeostasis. Numerous mRNAs are detected in microarray profiling of salivary glands for which no corresponding salivary proteins are yet known. Comparative analysis of salivary proteome and transcriptome (mRNAs) indicates concordant presence, and potential biomarkers await definition. ${ }^{75}$

\section{REFERENCES:}

1. Almughrabi OM, Marzonk KM, Hasqnato KM, Shafik SS. Melatonin levels in periodontal health and disease. J Periodontal Res. 2013;48:315-21.

2. James TR, Hiroshi S. Understanding salivary fluid and protein secretion. Oral Dis. 2002;8:3-11.

3. Amerongen AV, Bolscher JG, Veerman EC. Salivary proteins: protective and diagnostic value in cariology? Caries Res. 2004;38:247-53.

4. Johan KM, Martens LC. Review: The physiology of saliva and transfer of drugs into saliva. Forensic Science International. 2005;150:119-31.

5. Amerongen AV, Veerman EC. Saliva: The defender of the oral cavity. Oral Dis. 2002;8:12-22.

6. Atkinson JC, Baum BJ. Salivary enhancement: Current status and future therapies. J Dental Educ. 2001; 65:1096-1101.

7. Bqquero AF, Gilbertson TA. Insulin activates epithelial sodium channel via phosphoinisitide 3 kinase in mammalian taste receptor cells. Am J Physiol Cell Physiol. 2011; 300:C860-71.

8. Barabosh RD, Levitski AR. Enzymatic mechanisms for antimicrobial protection of the oral cavity. Vopt Med Khim (Russian). 1978;24:291-310. 
9. Bardo WA, Hofer E, Nyvad B et al. Effect of whole saliva composition on experimental root caries. Caries Res. 2005; 39:71-7.

10. Baron A, DeCarlo A, Featherstone J. Functional aspects of the human salivary Cystatins in the oral environment. Oral Dis. 1999;5:234-40.

11. Bennick A, Kells D, Madapallimattan G. Interactions of calcium ions and salivary acidic proline rich proteins with hydroxyapatite: a possible aspect of inhibition of hydroxyapatite formation. Biochem J. 1983;213:11-20.

12. Borella P, Fantuzzi G, Aggazzotti G. Trace elements in saliva and dental caries in young adults. Sci Total Environ. 1994;153:219-24.

13. Byzaluf MA, Hannas AR, Kato MT. Saliva and dental erosion. J Appl Oral Sci. 2012;20:493-502.

14. Choussain-Miller C, Fioretti F, Goldberg M, Menashi $\mathrm{S}$. The role of matrix metalloproteinases in human caries. J Dent Res. 2006;85:22-32.

15. Ciancio SG. Medications as risk factors for periodontal disease. J Periodontal. 1996;67:1055-59.

16. Cunha-Cruz J, Scott J, Rothem M et.al. Salivary characteristics and dental caries: Evidence from general dental practices. J Am Dent Assoc. 2013; 144:e31-e40.

17. Docray GJ. Luminal sensing in the gut: an overview. J Physiol Pharmacol. 2004;54:9-17.

18. Duggal MS, Chawla HS, Curzon ME. A study of the relationship between trace elements in saliva and dental caries in children. Arch Oral Biol. 1991;36:881-84.

19. Ekstrom J, Ekman R, Hakanson R et.al. Calcitonin gene related peptide in rat salivary glands: neuronal localization, depletion upon nerve stimulation and effect on salivation in relation to substance $P$. Neuroscience. 1988;26:933-49.

20. Ekstrom J, Aszlely A, Tobin G. Parasympathetic nonadrenergic noncholinergic mechanisms in salivary glands and their role in reflex secretion. Eur J Morphol. 1998;36:208-12.

21. Elson AE, Doston CD, Egan JM, Munger SD. Glucagon signalling modulated sweet taste responsiveness. FASEB J. 2010;24:3960-69.

22. Enberg N, Alho H, Loimaranta V, LenanderLumikari M. Saliva flow rate, amylase activity and protein and electrolyte concentrations in saliva after acute alcohol consumption. Oral Surg Oral Med Oral Pathol. 2001;92:292-98.

23. Fejereskov O, Kidd E. Dental caries: The disease and its clinical management. 1st ed, Oxford. Blackwell Munksgaard Ltd. 2003.

24. Fujikawa H, Matsuyama K, Uchiyama A, Nakashima $\mathrm{S}$, Ujire T. Influence of salivary macromolecules and fluoride on enamel lesion reminerallization in vitro. Caries Res. 2008; 42:37-45.
25. Gabriel MO, Grunleid T, Zentner A. Glycosylation pattern and cell attachment inhibiting property of human salivary mucins. J Periodontal. 2005;76:1175-81.

26. Garcia-Godov F, Hicks MJ. Maintaining the integrity of enamel surface: The role of dental biofilm, saliva and preventive agents in enamel demineralization and reminerallization. J Am Dent Assoc. 2008;139:25s-34s.

27. Garett JR. The proper role of nerves in salivary secretion- a review. J Dent Res. 1987;66:387-97.

28. Garnowicz A, Bielawaska A, Bielawski K. Proinflammatory cytokines in saliva of adolescents with dental caries disease. Ann Agric Environ Med. 2012;19:711-16.

29. Groschl M. The physiological role of hormones in saliva. Bioessays. 2009;31:843-53.

30. May DI, Smith DJ, Schlackebier SK, Moreno EC. Relationship between concentration of human salivary statherin and inhibition of calcium phosphate precipitation in stimulated human parotid saliva. J Dent Res. 1984; 63:857-63.

31. Helmerhorst EJ, Oppenheim FG. Saliva: a dynamic proteome. J Dent Res. 2007;86:680-93.

32. Henskens YM, Strooker H, van den Keijbus PA. Salivary protein composition in epileptic patients on different medications. J Oral Pathol Med. 1996;25:360-6.

33. Ikabe K, Matsuda K, Kagawa R. Association of masticatory performance with age, gender, number of teeth, occlusion free and salivary flow in Japanese older adults: is aging a risk factor for masticatory dysfunctions? Arch Oral Biol. 2011;56:991-6.

34. Ishijima T, Koshino H, Hirai T. The relation between salivary secretion rate and masticatory efficiency. J Oral Rehabil. 2004;31:3-6.

35. Jawed M, Shahid SM, Qader SA, Azhar A. Dental caries in diabetic mellitus: role of salivary flow rate and minerals. J Diabetic Complications. 2011;25:183-6.

36. Johnson AR. Observations on calcium mediated stability of salivary proteins in a lipid extraction system. J Dent Res. 1976;55:470-5.

37. Johansson I, Saellstom AK, Rajan BP, Parmeswaram A. Salivary flow and dental caries in Indian children suffering from chronic malnutrition. Caries Res. 1992;26:38-43.

38. Kamodyova N, Tothova L, Celec P. Salivary markers of oxidative stress and antioxidant status: influence of external factors. Dis Markers. 2013;34:313-21.

39. Kapas S, Pahal K, Cruchley AT. Expression of adrenomedulin and its receptors in human salivary tissue. J Dent Res. 2004;83:333-7.

40. Lamy E, deCosta G, Santos R. Effect of condensed tannin ingestion in sheep and goat parotid saliva proteome. J Anim Physiol Anim Nutr. 2011;95:304-12.

41. Langerhof F, Oliveby A. Caries protective factors in 
saliva. Adv Dent Res. 1994;8:229-38.

42. Larsen MJ, Pearce EI. Saturation of human saliva with respect to calcium salts. Arch Oral Biol. 2003;48:317-22.

43. Lendenmann U, Grogan J, Oppenheim FG. Saliva and dental pellicle-a review. Adv Dent Res. 2000; 14:22-28.

44. Lima DP, Diniz DG, Molmaz SAS. Saliva: Reflection of the body. Int J Infect Dis. 2010;14:e184-8.

45. Sebastien JCF, Ourania K, Stephen JG, Renshaw D. Saliva: Physiology and diagnostic potential in health and disease. Sci World J. 2010;10:434-56.

46. Lukacs JR, Largaespada LL. Explaining sex differences in dental caries prevalence: saliva hormones and lifestyle etiologies. Am J Human Biol. 2006;18:540-65.

47. Raj PA, Johnson M, Levine MJ. Salivary statherine. J Biol Chem. 1992;207:5968-76.

48. Nordbo H, Darwish S, Bhatnagar RS. Salivary viscosity and lubrication: influence of $\mathrm{pH}$ and calcium. Scand J Dent Res. 1984;92:306-14.

49. Raynal BD, Hardinghsm TE, Sheehan JK. Calcium dependent protein interactions in MUC 5B provide reversible cross links in salivary mucus. J Biol Chem. 2003;278:28703-10.

50. Young A, Rykke M, Smistad G. On the role of human salivary micelle like globules in bacterial agglutination. Eur J Oral Sci. 1997;105:485-94.

51. Zaichk VE, Bagirao ST. The chemical element content of mixed unstimulated saliva in periodontal diseases. Stomatologia (Mosk). 1994;73:8-11.

52. Veerman EC, Valentign-Benz M, Amerongen AV. Viscosity of human salivary mucus: effect of $\mathrm{pH}$ and ionic strength and role of sialic acid. J Biol Buccale. 1989;17:297-306.

53. Tabassum ST, Nayak RP. Salivary blood group antigens and microbial flora. Int J Dent Hyg. 2011; 9:117-21.

54. Pollock JJ, Goodman G, Elsey PK. Synergism of lysozyme, proteinases and inorganic monovalent anions in the bacteriolysis of oral streptococcus mutans GS5. Arch Oral Biol. 1983;28:865-71.

55. Oudhoff MJ, Bolscher JGM, Nazmi K. Histatins are the major wound closure stimulating factors in human saliva as identified in cell culture assay. FASEB J. 2008;22:3805-12.

56. Teng CT. Lactoferin gene expression and regulation: a review. Biochem Cell Biol. 2002;80:7-16.

57. Valenti P, Antonnini C. Lactoferin- an important host defence against microbial and viral attack. Cell Mol Life Sci. 2005;62:2576-87.

58. Puddu P, Latorre D, Valenti P. Immuno-regulatory role lactoferin-lipopolysaccharide interactions. Biometals. 2010;23:387-97.

59. Teeuw W, Busch JA, Veerman EC. Neuroendocrine regulation of salivary $\operatorname{Ig}$ A synthesis and secretion: implications for oral health. Biol Chem. 2004;385:1137-46.

60. Matos-Gomes N, Katsurayama M, Makimoto FH. Psychological stress and its influence on salivary flow rate, total protein concentration and $\mathrm{IgA}, \operatorname{IgG}$ and $\operatorname{IgM}$ titers. Neuroimmunomodulation. 2010;17:396-404.

61. Ring C, Caroll D, Hoving J. Effect of competition, exercise and mental stress on secretory immunity. J Sports Sci. 2005;23:501-8.

62. Tomassi TB, Tan EM, Solomon A. Characterization of an immune system common to certain external secretions. J Exp Med. 1965;121:101-25.

63. Sabbadini E, Berzi I. the sunmandibular gland: a key organ in the neuroimmunoregulatory network. Neuroimmunomodulation. 1995;2:184-202.

64. Yue Y, Liu Q, Xu C. Comparative evaluation of cytokines in gingival crevicular fluid and saliva in patients with aggressive periodontitis. Int J Biol Markers. 2013;28: e108-12.

65. Tabi TK, Fegerdy P. Saliva in health and diseaseclinical biology of Willey Encyclopedia of chemical Biology. Wiley international Inc, London. 2007.

66. Shubinikova EA, Volkova EF, Printseva O. Submandibular gland as organ of synthesis and accumulation of insulin like protein. Acta Histochem. 1984; 74:157-71.

67. Messenger B, Clifford MN, Morgan LM. Glucose dependent insulin-tropic polypeptide and insulin like immune-reactivity in saliva following sham fed and swallowed meals. J Endocrinol. 2003;177:407-12.

68. Shin YK, Martin B, Kim W. Ghrelin is produced in taste cells and ghrelin receptor null mice show reduced taste responsivity to salty and sour tastants. PLoS One. 2010; 5 e12729.

69. Shigemura N, Otha R, Kusakabe Y. Leptin modulates behavioural responses to sweet substances by influencing peripheral taste structures. Endocrinology. 2004; 145:839-47.

70. Raybould HE. Nutrient sensing in the gastrointestinal tract: possible role of nutrient transporters. J Physiol Biochem. 2008;64:349-56.

71. Qannan A. Burning mouth syndrome-a review. J Pakistan Dental Assoc. 2010;19:41-3.

72. Tiwari M. Science behind human saliva. J Natural Sci Biol Med. 2012;2:53-6.

73. Tenovuo J. Salivary parameters of relevance for assessing caries activity in individuals and populations. Comm Dent Oral Epid. 1997;25:82-6.

74. Wade WG. New aspects and new concepts of maintaining microbiological health. J Dent. 2010;38:21s-5s

75. Yan W, Apweiler R, Balgley BM. Systematic composition of the human saliva and plasma proteomes. Proteomics Clin Appl. 2009; 3:116-134. 